\title{
Effect of Different Application Methods of Zinc and Boron on Growth and Yield of Cabbage
}

\author{
Rafia Hasan Taheri, Md. Shipon Miah, Md. Golam Rabbani, Md. Abdur Rahim
}

\begin{abstract}
Zinc and boron are the most important trace nutrients for crop production. In recent years, cultivable lands in Bangladesh suffer deficiency of these elements. This research aimed to find out a suitable and effective application method to improve the overall soil nutrient up-gradation for crop production. Here, the treatments were control $\left(T_{0}\right)$, soil application of zinc $\left(T_{1}\right)$, soil application of boron $\left(T_{2}\right)$, foliar application of zinc $\left(T_{3}\right)$, foliar application of boron $\left(T_{4}\right)$, soil application of zinc and boron $\left(\mathrm{T}_{5}\right)$, soil application of zinc with foliar application of boron ( $\left.\mathrm{T}_{6}\right)$, soil application of boron with foliar application of zinc $\left(\mathrm{T}_{7}\right)$, and foliar application of zinc and boron ( $\left.T_{8}\right)$. The source of zinc @ $3 \mathrm{~kg} \mathrm{ha}^{-1}$ and boron @ $2 \mathbf{k g}$ $\mathrm{ha}^{-1}$ as a basal dose were zinc sulphate and borax, respectively. The foliar application of zinc and boron was done at 45 and 60 days after transplanting @ 1\% and the source were chelated zinc and solubor boron, respectively. The result of the experiment was concerning the highest plant height, plant spreading, the number of leaves, stem length, stem diameter, fresh weight of loose leaves, head diameter, head thickness, dry matter content of head, and yield. The highest yield of cabbage was found with the treatment foliar application of zinc and boron $\left(T_{8}\right)$. The results of this investigation revealed that the application methods of zinc and boron positively affect the growth and yield of cabbage whereas foliar application of these nutrients always makes higher growth parameters with yield.
\end{abstract}

Index Terms - application method, boron, cabbage, micronutrient, zinc.

\section{INTRODUCTION}

Cabbage (Brassica oleracea var. capitata L.) belongs to the Cruciferae and is one amongst the foremost important leafy vegetables in Bangladesh [1]. It is a biennial and herbaceous crop, which is widely grown in temperate regions of the world [2]. The cultivation of cabbage in Bangladesh is mainly limited to winter months. The edible portion of the cabbage plant is known as 'head' that is made up of numerous thick and overlapping smooth leaves. As a vegetable, cabbage has high nutritive value [3]. An edible portion of $100 \mathrm{~g}$ of cabbage contains energy value of $24 \mathrm{Cal}$, moisture $90.2 \mathrm{~g}$, protein $1.6 \mathrm{~g}$, fat $0.2 \mathrm{~g}$, fiber $0.9 \mathrm{~g}$,

Published on August 29, 2020.

R. H. Taheri, Department of Horticulture, Bangladesh Agricultural University, Bangladesh.

(e-mail: ht.rafia ${ }^{\circledR}$ gmail.com)

M. S. Miah, Department of Horticulture, Bangladesh Agricultural University, Bangladesh.

(e-mail: m.shipon.dae ${ }^{@}$ gmail.com)

M. G. Rabbani, Department of Horticulture, Bangladesh Agricultural University, Bangladesh.

(e-mail: drmgrabbani@ gmail.com)

M. A. Rahim, Department of Horticulture, Bangladesh Agricultural University, Bangladesh.

(e-mail: marahim1956@bau.edu.bd) carbohydrate $4.8 \mathrm{~g}$, calcium $0.05 \mathrm{~g}$ phosphorus $0.04 \mathrm{~g}$, vit-B1 $0.06 \mathrm{mg}$, Vit-B2 $0.05 \mathrm{mg}$, Vit-B5 $0.4 \mathrm{mg}$ and Vit-C 55mg [4].

Cabbage is one of the fiber leading vegetables in the world, which is extensively grown in Bangladesh [5]. In Bangladesh, the ranking of cabbage is third concerning production and first in relation to per hectare yield of winter vegetables [6]. It is cultivated in a part of 18620 hectares of land with gross production of 322000 tons containing per hectare yield of 17.33 tons [6]. However, the yield of cabbage in Bangladesh is incredibly low compared to developed countries [7]. This low yield of cabbage could be raised by adopting improved production practices. Adoption of improved production practice including judicious application of manures and fertilizers can significantly increase the yield of cabbage. Nutrients could also be applied both from organic and inorganic sources. Micronutrients using have positive effect for soil health in regard to the properties of soil by water holding capacity, texture, structure, soil aeration, color, microbial activity etc. Soils properties of Bangladesh contain but $2 \%$ organic matter in most of the regions [8]. Besides this, inorganic fertilizer especially micronutrients applications have always proved advantageous for supply of nutrients. The mixed application method of micronutrients might help in balancing nutrient supply as well as maintaining good soil health. Moreover, micronutrients play distinct and vital roles in plant physiological and biochemical processes [9].

Among the assorted production practices, ensuring available nutrients within the soil is incredibly important which is alleged to the judicious application of fertilizers. An oversized number of research work are conducted within the past on the effect of various fertilizer management practices on growth and yield of cabbage. To enhance the standard of cabbage, there should have the technologies which can eventually fulfill the growers further as consumers' need. Therefore, studies on management practices, particularly on the management of boron and zinc would help increasing quality and yield of cabbage. Available information during this regard under Bangladesh conditions is insufficient. The current study therefore conducted as to seek out the influence of application method of boron and zinc in presence of recommended doses with other fertilizers. In short, the yield response of cabbage because of application methods.

\section{MATERIALS AND METHOD}

\section{A. Site and soil}

The experimental site developed for research purpose was in subtropical and located at $24^{\circ} \mathrm{N}$ latitude and $91^{\circ} \mathrm{E}$ longitude having an elevation of 8.3 meters above the ocean level. Huge sunshine with moderate coldness features during 
rabi season favors the growing of cabbage. The soil is categorized as silty loam type, medium high land, $\mathrm{pH}$ ranging from 6.88 to 6.92 belonging to the Old Brahmaputra Flood Plain as agro-ecological zone-9 (AEZ-9) having noncalcareous dark grey flood plain soil [6].

\section{B. Planting materials, design and treatments}

The seedlings were raised at Horticulture Farm, Bangladesh Agricultural University, Mymensingh with intensive care in a $3 \mathrm{~m} \times 1 \mathrm{~m}$ seedbed. The prepared seedbed was ploughed well with spade for better tilth and favorable conditions to grow cabbage seedlings. On October 23, 2014 the seeds were sown and then covered with light soil. The main field was prepared by deep and cross ploughing with a tractor followed by laddering. The weeds and stubble were removed, and plots were made according to layout and design (RCBD) of the experiment. Drainages were made around each plot and the excavated soil was used for raising plots about $10 \mathrm{~cm}$ high from the soil surface. Twenty-one days old, healthy cabbage seedlings were transplanted at the experimental plot on November 13, 2014. The uprooting of seedlings was done carefully followed by light irrigation at least an hour earlier to minimize root damage. To provide better establishment time, afternoon period was selected for transplanting. During transplanting the spacing was maintained as per the design of the experiment.

\section{Intercultural operations}

At the end of germination, light irrigation and other cultural practices were provided as per the requirement of the field. To protect the seedlings from the attack of cutworm spraying with Melathion 57 EC @ $2 \mathrm{ml} \mathrm{L}^{-1}$ was done at 07 days of interval, regularly. The experimental plot was treated with prescribed dose of NPKS (Table I). All the fertilizer except urea, MoP, and foliar application of zinc and boron were applied during final land preparation in the respective plot. The rest of the urea and MoP were applied in 3 equal installments at 30, 45, and 60 DAT (days after transplanting). Each top dressing was followed by irrigation. The foliar application of zinc and boron was done at 45 and 60 days after transplanting @ 1\% and the source were chelated zinc and solubor boron, respectively. The seedlings were watered immediately after transplanting. The transplanted seedlings were provided with shade during scorching sunshine. The shading techniques were done with the help banana leaf sheath and this process was followed six days to provide favorable setting conditions to the soil. The shading mechanism was removed in night to favor the dew reception of the seedlings. Border plants were kept to provide in case of gap fillings. Supplementary irrigations were done by observing the soil moisture. Earthing up was done 03 times during weeding. To control cutworm and foot rot disease spraying with Melathion 57 EC @ $2 \mathrm{ml} \mathrm{L}^{-1}$ and Ridomil MZ 68 @ $\mathrm{g} \mathrm{L}^{-1}$ water done, respectively.

TABLE I: NUTRIENT RATE And SOURCE [10]

\begin{tabular}{cccc}
\multicolumn{4}{c}{ TABLE I: NutRIENT RATE And SouRCE [10] } \\
\hline Nutrients & Rate $\left(\mathrm{kg} \mathrm{ha}^{-1}\right)$ & Source & Amount $\left(\mathrm{kg} \mathrm{ha}^{-1}\right)$ \\
\hline $\mathrm{N}$ & 100 & Urea & 218 \\
$\mathrm{P}$ & 30 & TSP & 140 \\
$\mathrm{~K}$ & 60 & $\mathrm{MOP}$ & 120 \\
$\mathrm{Zn}$ & 3 & $\mathrm{ZnSO}_{4}$ & 8.5 \\
$\mathrm{~B}$ & 2 & Borax & 19 \\
\hline
\end{tabular}

\section{Harvesting and data collection}

The crop was harvested on 13 February 2015, when the heads become well compact with the maturity $80 \%$ of the cabbage. Personal judgment involved to select mature head. Harvesting with roots was done manually and very carefully without disturbing the roots and the leaves. As the central four plants of every plot were selected as samples. The data were collected from the sample plants from 30 days after transplanting (DAT) to 90 DAT with 15 days of interval for plant height, plant spread, number of loose leaves as parameters to be studied. During harvesting the final data from the sample plants were also collected for weight of the whole plant, stem length, stem diameter, root length, root weight, head weight, head diameter, head thickness, number of marketable head, yield of head per plot, per hectare yield and dry matter content as parameters to be studied. To measure dry matter content, $100 \mathrm{~g}$ of chopped head was taken from each plot and dried under sunlight. To ensure constant weight it was then dried at $70^{\circ} \mathrm{C}$ in an oven. Then percent dry matter in head $(\% \mathrm{DMH})$ was calculated. The following formula was used to calculate the $\% \mathrm{DMH}$.

$$
\% \mathrm{DMH}=\frac{\text { Dry weight of the head }}{\text { Fresh weight of head }} \times 100
$$

\section{E. Data analysis}

The collected data for different parameters were analyzed. The analysis was done following the statistical method to observe the effects on yield contributing characters of cabbage in respect of application methods of zinc and boron. The analysis of variance was performed by using the MSTAT program. The level of significance among the treatment means was evaluated by the least significant difference (LSD) test at 5\% level of probability [11].

\section{RESULTS AND DisCUSSION}

\section{A. Plant height, plant spread and number of loose leaves per plant}

Plant height (A in Fig. 1), plant spread (B in Fig. 1) and the number of loose leaves per plant (Table II) were collected from 30 DAT to 90 DAT at 15 days interval. It implies that the plant height, plant spread and the number of loose leaves were gradually increased with the period of the whole growing season, reached pick at 75 DAT and then gradually decreased. As the effects were significant, this means the combination of treatments in respect to application methods either soil or foliar or both have beneficial effect on the growth of cabbage. Which can be concluded as the appliance method of zinc and boron improved growth characters as results of soil and foliar application of micronutrients which might have enhanced photosynthesis and other metabolic activities and ultimately resulted from increase in the biological process like cell elongation and cell division [12].These results also support the findings of Nayak and Nandi [13]. In $\mathrm{T}_{8}$ (foliar application of zinc and boron @ 1\%), the maximum plant height $(36.33 \mathrm{~cm})$, maximum plant spread $(57.42 \mathrm{~cm})$ and maximum loose leaves (17) were recorded and the lowest result for these parameters were found in $\mathrm{T}_{0}$ (control). 


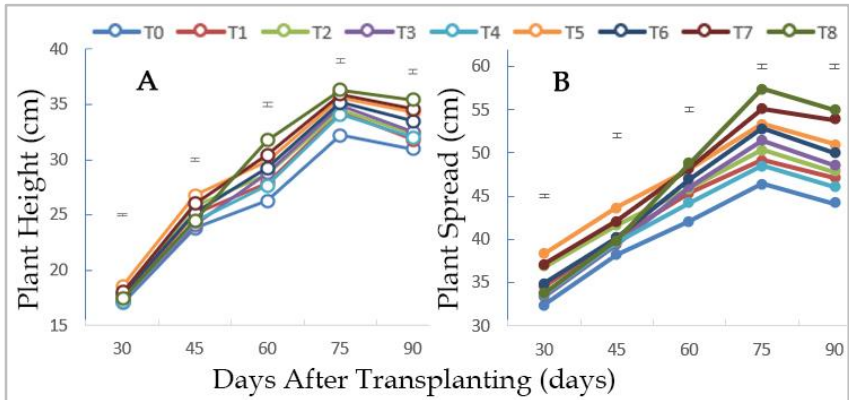

Fig. 1. Plant height and spread of cabbage affected by different application method of zinc and boron. The vertical bars represent LSD at 5\% level of probability.

TABLE II: LoOse LeAVES Number Of CABBAges AFFECTED BY DIFFERENT METHODS OF APPLICATION AT DIFFERENT DAYS AFTER TRANSPLANTING (DAT)

\begin{tabular}{cccccc}
\hline & \multicolumn{5}{c}{ Loose leaves number } \\
\cline { 2 - 6 } Treatment & 30 & 45 & 60 & 75 & 90 \\
& DAT & DAT & DAT & DAT & DAT \\
\hline $\mathrm{T}_{0}$ & 9 & 12 & 12 & 11 & 10 \\
$\mathrm{~T}_{1}$ & 9 & 12 & 13 & 13 & 13 \\
$\mathrm{~T}_{2}$ & 10 & 13 & 13 & 13 & 13 \\
$\mathrm{~T}_{3}$ & 9 & 13 & 15 & 15 & 15 \\
$\mathrm{~T}_{4}$ & 9 & 12 & 13 & 12 & 12 \\
$\mathrm{~T}_{5}$ & 11 & 12 & 16 & 15 & 15 \\
$\mathrm{~T}_{6}$ & 9 & 12 & 16 & 15 & 15 \\
$\mathrm{~T}_{7}$ & 10 & 12 & 16 & 15 & 15 \\
$\mathrm{~T}_{8}$ & 9 & 12 & 16 & 17 & 16 \\
\hline LSD 0.05 & 0.58 & 0.62 & 0.45 & 0.72 & 0.45 \\
\hline Level of & $* *$ & $* *$ & $* *$ & $* *$ & $* *$ \\
significance & & & &
\end{tabular}

\section{B. Whole plant weight, stem length and stem diameter}

The results showed significant variation among the various combination of application methods of zinc and boron in relation to the whole plant weight, stem length and stem diameter (Table III). Treatment with $\mathrm{T}_{8}$ showed the highest whole plant weight, highest stem length and highest stem diameter. And the lowest results were found with the application of $\mathrm{T}_{0}$ in all cases (Table III). As zinc and boron is responsible for the plant growth through different biosynthesis of hormones [14]. This could be therefore attributed as role of micronutrients (zinc, boron) in the biological process like cell expansion or cell division. Similar results also found by Kasturikrishana and Ahlawat [15] in pea.

TABLE III: EFFECTS For THE ApplicAtion Methods Of ON WhOlE Plant Weight (Wt.), Stem Length, Stem Diameter, Root Weight, ROOT LENGTH AND LOOSE LEAVES WEIGHT

\begin{tabular}{|c|c|c|c|c|c|c|}
\hline Treatment & $\begin{array}{l}\text { Whole } \\
\text { plant } \\
\text { wt. } \\
\text { (kg) }\end{array}$ & $\begin{array}{l}\text { Stem } \\
\text { length } \\
(\mathrm{cm})\end{array}$ & $\begin{array}{c}\text { Stem } \\
\text { diameter } \\
(\mathrm{cm})\end{array}$ & $\begin{array}{l}\text { Root } \\
\text { weight } \\
\text { (g) }\end{array}$ & $\begin{array}{l}\text { Root } \\
\text { length } \\
(\mathrm{cm})\end{array}$ & $\begin{array}{c}\text { Loose } \\
\text { leaves } \\
\text { weight } \\
(\mathrm{kg})\end{array}$ \\
\hline $\mathrm{T}_{0}$ & 1.88 & 9.03 & 4.03 & 41.33 & 17.92 & 0.70 \\
\hline $\mathrm{T}_{1}$ & 2.02 & 9.75 & 4.65 & 47.33 & 21.33 & 0.76 \\
\hline $\mathrm{T}_{2}$ & 2.04 & 10.08 & 4.74 & 50.00 & 22.70 & 0.79 \\
\hline $\mathrm{T}_{3}$ & 2.11 & 10.50 & 4.91 & 50.25 & 23.25 & 0.82 \\
\hline $\mathrm{T}_{4}$ & 1.98 & 9.49 & 4.55 & 44.33 & 20.57 & 0.75 \\
\hline $\mathrm{T}_{5}$ & 2.22 & 11.00 & 4.29 & 55.25 & 26.23 & 0.82 \\
\hline $\mathrm{T}_{6}$ & 2.12 & 10.50 & 5.11 & 53.33 & 24.62 & 0.79 \\
\hline $\mathrm{T}_{7}$ & 2.42 & 10.81 & 5.41 & 57.54 & 27.60 & 0.84 \\
\hline $\mathrm{T}_{8}$ & 2.54 & 11.17 & 5.81 & 59.67 & 28.92 & 0.89 \\
\hline $\mathrm{LSD}_{0.05}$ & 0.116 & 0.581 & 1.008 & 1.03 & 0.21 & 0.03 \\
\hline $\begin{array}{c}\text { Level of } \\
\text { significance }\end{array}$ & $* *$ & $* *$ & $*$ & $* *$ & $* *$ & $* *$ \\
\hline
\end{tabular}

$*=$ significant at $5 \%$ level, $* *=$ significant at $1 \%$ level.

\section{Root weight and root length}

The present study reveals significant effects on root weight and root length (Table III) in respect of the application methods of zinc and boron. The maximum weight of root $(59.67 \mathrm{~g})$ and root length $(17.92 \mathrm{~cm})$ were found with the application of recommended doses of NPKS with foliar application of zinc and boron @ $1 \%\left(\mathrm{~T}_{8}\right)$ and minimum weight of root, as well as the lowest root length, were found from recommended doses of NPKS $\left(\mathrm{T}_{0}\right)$. This is because of the application methods of micronutrients with NPKS combined use. It makes the nutrients available and increases biomass yield. As a result, better growth and development of roots occurred. This finding partially supports the results of Wei et al. [16].

\section{Head weight, head diameter and heat thickness}

The results populated significant relations of application method in the parameters of head weight, head diameter and head thickness (Table IV). This may be due to the application methods in soil or foliage, which have enhanced the metabolic activities of zinc and boron and lead to increase in intra cellar activities like cell division or cell elongation [12]. As these parameters are for the reason of leaves, which means the probability of adequate availability of nutrients by the recommended dose of NPKS along with the application of soil or foliar zinc and boron. These results also support the findings of Hou [17].

\begin{tabular}{|c|c|c|c|c|c|}
\hline Treatment & $\begin{array}{c}\text { Head } \\
\text { weight } \\
(\mathrm{kg})\end{array}$ & $\begin{array}{c}\text { Head } \\
\text { diameter } \\
(\mathrm{cm})\end{array}$ & $\begin{array}{c}\text { Head } \\
\text { thickness } \\
(\mathrm{cm})\end{array}$ & $\begin{array}{l}\text { Yield } \\
\left(\mathrm{t} \mathrm{ha}^{-1}\right)\end{array}$ & $\begin{array}{c}\mathrm{DMH} \\
(\%)\end{array}$ \\
\hline $\mathrm{T}_{0}$ & 1.13 & 17.52 & 4.47 & 29.65 & 3.53 \\
\hline $\mathrm{T}_{1}$ & 1.19 & 18.69 & 4.82 & 31.74 & 3.78 \\
\hline $\mathrm{T}_{2}$ & 1.16 & 18.72 & 5.03 & 34.24 & 3.94 \\
\hline $\mathrm{T}_{3}$ & 1.23 & 19.00 & 5.23 & 36.18 & 4.15 \\
\hline $\mathrm{T}_{4}$ & 1.15 & 18.62 & 4.68 & 33.13 & 3.63 \\
\hline $\mathrm{T}_{5}$ & 1.31 & 19.76 & 6.88 & 40.56 & 4.52 \\
\hline $\mathrm{T}_{6}$ & 1.24 & 19.51 & 6.55 & 37.85 & 4.32 \\
\hline $\mathrm{T}_{7}$ & 1.52 & 20.43 & 7.30 & 45.90 & 4.64 \\
\hline $\mathrm{T}_{8}$ & 1.57 & 21.57 & 7.77 & 50.90 & 5.02 \\
\hline $\mathrm{LSD}_{0.05}$ & 0.12 & 0.26 & 0.19 & 1.18 & 0.14 \\
\hline $\begin{array}{c}\text { Level of } \\
\text { significance }\end{array}$ & $* *$ & $* *$ & $* *$ & $*$ & $* *$ \\
\hline
\end{tabular}

$*=$ significant at $5 \%$ level and $* *=$ significant at $1 \%$ level.

\section{E. Yield and percent dry matter content}

There was remarkable variation found in case of yield and dry matter content of cabbage by the application methods of zinc and boron (Table IV). The result reveals that, the maximum number of the marketable head was 16, the highest yield was $50.90 \mathrm{t} \mathrm{ha}^{-1}$ and the maximum dry matter content was $5.02 \%$. And all of these were found with the application of $\mathrm{T}_{8}$. Whereas the minimum result of these parameters was found with the application of $T_{0}$. The variations of yield and dry matter content in head leaves were highly significant by the application methods of zinc and boron. This is maybe because of qualitative and quantitative parameters influenced by the application of zinc and boron [18]. These findings support the investigation of Hajiboland and Amirazad [19], they reported that dry matter 
production of shoot and root was reduced by low zinc supply.

\section{CONCLUSION}

The production of cabbage influenced greatly by the application of micronutrients mostly by zinc and boron. The present investigation made to find out the appropriate combination method of application (soil or foliar) of the recommended dose of zinc and boron with other recommended doses of fertilizers. The study shows that soil and foliar application methods of zinc and boron with prescribed dose of NPKS influenced the growth and yield of cabbage. Whereas, the application of these as foliar always produce better results for growth parameters. However, to reach a specific conclusion further research work on the growth of cabbage needs to be done in different regions of Bangladesh.

\section{REFERENCES}

[1] Hoq, M. S., M. A. Matin, T. M. B. Hossain, S. Hossain. 2014 Cabbage (Brassica oleracea) and cauliflower (Brassica oleracea) marketing in selected areas of Bangladesh. Bangladesh Journal of Agricultural Research. 39(1): 127-141.

[2] Alfred, R. C. and S. Thomas. 2007. World Food: Production and Use. John Wiley \& Sons, New Jersey, United States, pp. 464.

[3] Adelanwa, E. B. and J. M. Medugu. 2015. Variation of the nutrient composition of red and green cabbage (Brassica oleracea) with respect to age at harvest. Journal of Applied Agricultural Research. 7: 183-189.

[4] Rumeza, H., I. Zarfar, I. Mudassar, H. Shaheena and R. Masooma 2006. Use of vegetables as nutritional food: role in human health. Journal of Agricultural and Biological Science. 1(1): 18-22.

[5] Rashid, M. M. 1993. Shabjee Biggan (in Bengali). First edition, Bangla Academy, Dhaka, pp. 179-196.

[6] BBS. 2020. Yearbook of Agricultural Statistics - 2019. Bangladesh Bureau of Statistics, Statistics Division, Ministry of Planning, Govt. of the People's Republic of Bangladesh, Dhaka, pp. 669.

[7] FAO. 1999. Production Yearbook. Food and Agriculture Organization of United Nations, Rome, Italy, pp. 147-148.

[8] Bhuiyan, N. I. 1994. Crop production and need of sustainability in agriculture. A paper presented in a three day workshop on "Integrated Nutrient Management for Sustainable Agriculture" held at SRSI, June 26-28.

[9] Putra, E. T. S., W. Zakaris, N. A. P. Abdullah and G. B. Saleh. 2012. Stomatal morphology, conductance and transpiration of Musa sp. cv. Rastali in relation to magnesium, boron and silicon availability. American Journal of Plant Physiology. 7: 84-96.

[10] BARC. 2012. Fertilizer Recommendation Guide - 2012. Bangladesh Agricultural Research Council, Farmgate, Dhaka 1215, pp. 274.

[11] Gomez, K. A. and A. A. Gomez. 1984. Statistical Procedure for Agricultural Research (2nd Edition). International Rice Research Institute, A Willey International Science Publication, pp. 28-192.

[12] Hatwar, G. P., S. U. Gondane, S. M. Urkude and O. V. Gahukar 2003. Effect of micronutrients on growth and yield of chilli. Journal of Soil Crops. 13: 123-125.

[13] Nayak, S. C. and A. Nandi. 2008. Performance of hybrid cabbage (Brassica olearacea var. capitata) as influenced by foliar micronutrient sprays. Vegetable Science. 35(1): 45-48.

[14] Bhatt, B., K. Srevastava and M. P. Singh. 2004. Studies on the effect of foliar application of micronutrients on growth, yield and economics of tomato (Lycopersicon esculentum Mill). Progressive Horticulture. 36 (2): 331-334.

[15] Kasturikrishna, S. and I. P. S. Ahlawat. 2003. Effect of moisture stress, phosphorus, sulphur and zinc fertilizers on growth and development of pea (Pisum sativum). Indian Journal of Agronomy. 45 (2): $353-356$

[16] Wei, W. J., W. Z. Hui, Z. H. Bingh, Z. Y. Ling and L. M. Hua. 2012 Effect of Se, Zn and Mo on Yield and Contents of Nutrient Elements and Selenium and Cadmium of Potato and Cabbage on the Loess Plateau. Journal of Agro-Environment Science. 12(11): 2114-2120.

[17] Hou, Z. Y. and Z. N. Shang. 2006. Effects of Zinc and Boron microelement fertilizer on yield and quality of cabbage. Journal of China Agriculture. 23: 122-125.
[18] Batra, B. R. and G. Kalloo. 1990. Effect of different levels of irrigation and fertilization on growth and yield of carrot for root production. Vegetable Science. 17 (2): 127-139.

[19] Hajiboland, R. and F. Amirazad. 2010. Growth, photosynthesis and antioxidant defense system in $\mathrm{Zn}$-deficient red cabbage plants. Plant Soil Environment. 56(5): 209-217.

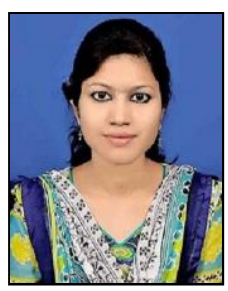

Rafia Hasan Taheri born in Jamalpur, Bangladesh. She graduated from Bangladesh Agricultural University (MS in Horticulture) in 2015. Currently she is serving as ASSISTANT GENERAL MANAGER (ADMIN/HR) with the supervision of Bangladesh Rural Electrification Board (BREB). She was a Graduate Research Fellow at the Department of Horticulture in Bangladesh Agricultural University. During her service period she attended different types of training, workshop, seminar and courses arranged by national and international bodies. Rafia Hasan Taheri is affiliated with the Krishibid Institution of Bangladesh (KIB) and Bangladesh Society for Horticultural Science. 